\title{
Pusat Tari Modern Dengan Pendekatan Arsitektur MetAFORA Di YogYaKaRTA
}

\author{
Fitri Kurnia Dewi, Maya Andria Nirawati, Hari Yuliarso \\ Program Studi Arsitektur \\ Universitas Sebelas Maret Surakarta \\ Email: fkdewi1993@gmail.com
}

\begin{abstract}
Designing Modern Dance Center in Yogyakarta motivated by the high public interest, especially among teenagers towards modern dance. The development of modern dance and many art events of modern dance especially in Yogyakarta, which the largest are Gatsby Dance Competition is held once a year, and United Dance World, held every two years, the main attraction of modern dance lovers community to creation and develop themselves. In addition, the modern dance community in Yogyakarta who have limited space and want a complete facilities, as well as comfort in doing activities, the purpose of this scheme is to make the concept of a platform for modern dance community in Yogyakarta with a view shape of the building that expresses movement of modern dance. Design issues are: how to realize the visual appearance of the building to express the movement of modern dance into the building design of Modern Dance Center. Characteristics are taken, namely the dynamic character embodied through order to see the buildings and mass; aesthetic character is realized through the interior view of the building, wall elements, and mass composition; and the contrast of the characters is realized through the whole mass. The method used is the method of architectural design. The result obtained is a design of a container for the modern dance community in Yogyakarta with the display form of the building expresses the characteristics of the modern dance movement.
\end{abstract}

Keywords: Architecture, Architectural Metaphor, Characteristics of Modern Dance, Modern Dance Center.

\section{PENDAHULUAN}

Tari modern muncul pada awal abad ke20 yang dipelopori oleh penari dari Amerika Serikat yaitu Martha Graham. Kemudian mulai perlahan masuk ke Indonesia dan sampai ke Yogyakarta pada tahun 1960 yang dibawa oleh Bagong Kussudiardja (Pramono, Adi Tri. 2015).

Perkembangan tari modern di Indonesia, khususnya di Yogyakarta saat ini sangat pesat. Hal ini merupakan suatu hal yang happening dan digemari oleh kalangan remaja. Maka dari itu, banyak muncul koreografer muda yang mengembangkan dan memperkaya nilai tari modern.

Yogyakarta saat ini terdapat banyak kegiatan dan acara kesenian tari. Hal ini merupakan potensi besar dibidang kesenian tari, khususnya tari modern. Salah satu acara tari modern adalah Gatsby Dance Competition yang diadakan setiap satu tahun sekali, dan United Dance World yang diadakan dua tahun sekali (Jogja Dance Foundation. 2011). Adanya acara tersebut menjadikan komunitas tari modern di Yogyakarta mulai mengembangkan dan berkreasi. Mereka menjadikan sanggar tari, gelanggang remaja, lapangan sekolah, hingga rumah pribadi sebagai tempat untuk berkumpul. Adapun sanggar tari yang ada, tidak memiliki fasilitas yang memadai sesuai fungsinya.

Dapat dilihat bahwa komunitas tari modern tidak mempunyai cukup ruang dan tempat untuk berlatih dan mengembangkan minat bakat mereka.

Maka dari itu, dibutuhkan wadah yang dapat menunjang kegiatan, memotivasi pecinta tari modern, maka desain bangunan, tata ruang, maupun fasad bangunan mempunyai peranan penting untuk menciptakan keseimbangan antara jiwa dan raga untuk para penari. Keseimbangan jiwa 
dan raga dapat diperoleh dari bentuk yang mudah diterima dan dipahami oleh penggunanya dengan cara pemindahan makna pada objek tertentu ke bentuk bangunan (Karatani, Kojin. 1995).

Pemilihan Arsitektur Metafora sebagai pendekatan dinilai sejalan dengan pemindahan makna tersebut. Pada Arsitektur Metafora, pemindahan makna dilakukan dengan cara memindahkan karakter suatu objek ke dalam bentuk arsitektural secara visual. Karakteristik yang diambil adalah karakteristik gerakan tari modern.

Dengan demikian, perlu adanya wadah bagi komunitas tari modern di Yogyakarta dengan tampilan bentuk bangunan yang mengakspresikan gerakan tari modern.

\section{METODE}

Metode yang digunakan dalam perancangan Pusat Tari Modern dengan Pendekatan Arsitektur Metafora dimulai dengan menuangkan seluruh hasil analisis melalui sketsa desain, yang akan terus berkembang menjadi bentuk yang sesuai dengan hasil analisis. Kemudian menyempurnakan bentuk tersebut dengan mengaplikasikan pendekatan Arsitektur Metafora melalui karakteristik gerakan tari modern. Karakteristik yang diambil yaitu dinamis, estetis, dan kekontrasan. Pada setiap tahapan, semakin berkembang, namun tetap dibatasi dengan hasil analisis yang diperoleh. Dari semua tahapan yang telah dilakukan, maka terbentuklah sebuah desain Pusat Tari Modern di Yogyakarta dengan Pendekatan Arsitektur Metafora.

\section{ANALISIS}

\subsection{Analisis Peruangan dan Luasan Ruang}

Analisis peruangan adalah sebagai faktor penting dalam menentukan luasan ruang yang direncanakan.

1. Tujuan:

Memperoleh kebutuhan dan luasan ruang.

2. Dasar Pertimbangan:

Pengelompokkan kegiatan dan pelaku kegiatan.

3. Hasil Analisis:

Konsep analisis pengguna pada Pusat Tari Modern di Yogyakarta adalah:

a. Seniman. b. Penari.

c. Pengunjung.

d. Pengelola.

e. Operator Teknis.

Berikut total luasan ruang yang dibutuhkan berdasarkan kelompok kegiatan:

a. Kegiatan latihan ekstern, intern, dan penciptaan karya: $1.277,7 \mathrm{~m}^{2}$.

b. Kegiatan pertunjukkan: $740 \mathrm{~m}^{2}$.

c. Kegiatan umum: $722,84 \mathrm{~m}^{2}$.

d. Kegiatan hunian: $220,69 \mathrm{~m}^{2}$.

e. Kegiatan pengelola: $1.618 \mathrm{~m}^{2}$.

f. Luas total: $4.579,23 \mathrm{~m}^{2}$.

g. Sirkulasi 80\%: 8.242,614 $\mathrm{m}^{2}$.

h. RTH 20\%: $1.648 \mathrm{~m}^{2}$.

i. Total area fungsional: $9.891,13 \mathrm{~m}^{2}$.

\subsection{Analisis Lokasi}

Pemilihan lokasi mempunyai peran dalam menentukan perkembangan tari modern.

1. Tujuan

Mendapatkan lokasi yang sesuai untuk bangunan Pusat Tari Modern.

2. Dasar pertimbangan:

a. Tapak dekat dengan pusat Kota Yogyakarta.

b. Terdapat banyak komunitas tari modern di kawasan Kabupaten Sleman (Jogja Dance Foundation. 2011).

c. Tapak memiliki infrastruktur yang lengkap.

\section{Hasil Analisis:}

Lokasi terpilih untuk Pusat Tari Modern terletak di Kabupaten Sleman, Yogyakarta. Tepatnya di Jalan Kapten Haryadi (Gambar 1).

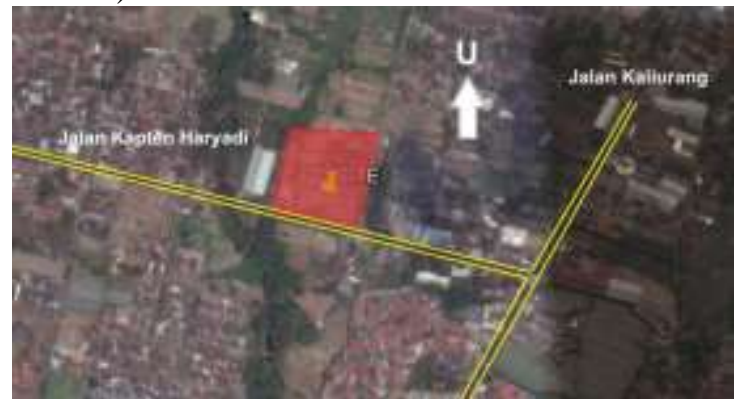

Gambar 1. Gambaran Lokasi Tapak

Batas tapak sebagai berikut:
a. Utara : Persawahan.
b. Timur : Perumahan.
c. Selatan : Rumah penduduk dan tanah lapang.
d. Barat : Rumah penduduk. 


\subsection{Analisis Pencapaian}

Pencapaian ke dalam bangunan harus mudah diakses, mudah dilihat dan memiliki sirkulasi yang aman akan menstimulus orang untuk masuk dalam area bangunan.

1. Tujuan: menentukan main entrane.

2. Dasar Pertimbangan: kemudahan akses, sirkulasi tapak yang aksesibel, arus kendaraan dan potensi jalan.

3. Hasil Analisis: Main Entrance diletakkan di Jalan Kapten Haryadi. (Gambar 2).

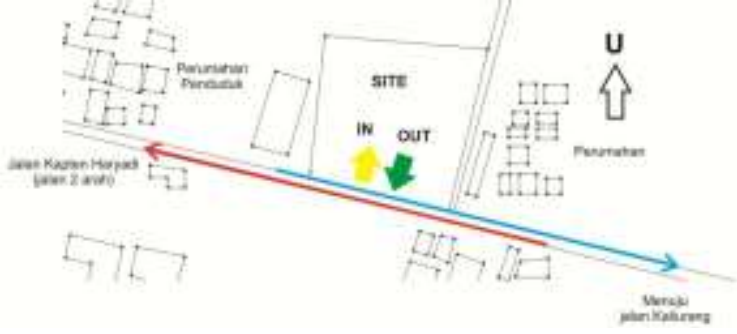

Gambar 2. Pola Pencapaian

\subsection{Analisis Sinar Matahari}

Sinar matahari sebagai pencahayaan alami harus dimanfaatkan secara efektif guna menghemat energi buatan dalam hal pencahayaan (Gambar 3).

1. Tujuan: memanfaatkan sinar matahari sebagai pencahayaan alami.

2. Dasar pertimbangan: arah datang sinar matahari, sifat yang dihasilkan dari sinar matahari terhadap manusia.

3. Hasil analisis: sinar matahari dimanfaatkan sebagai pencahayaan alami dengan memaksimalkan bukaan pada bangunan. Menggunakan barrier berupa tanaman dan sun shading (Gambar 4).

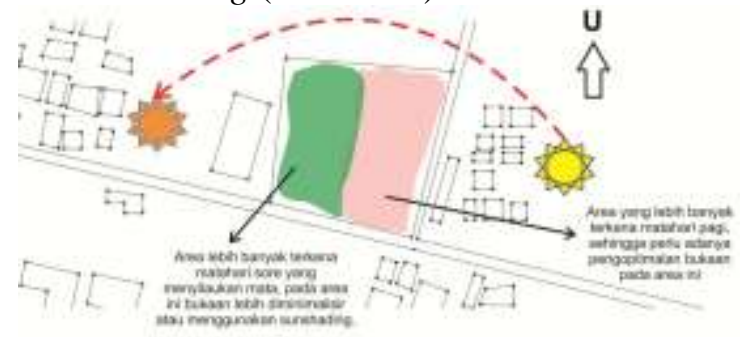

Gambar 3. Analisis Penyinaran Matahari

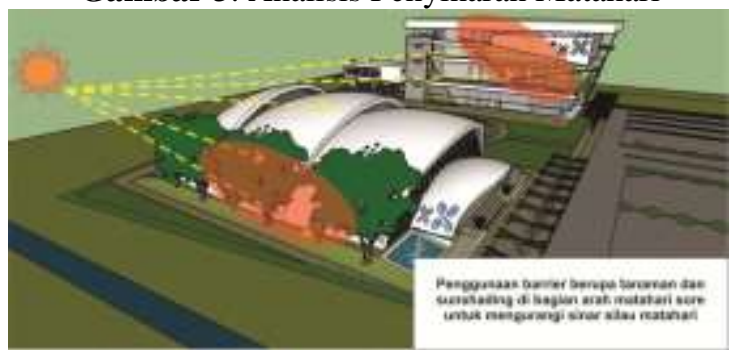

Gambar 4. Respon Desain

\subsection{Analisis View}

View digunakan untuk menentukan arah hadap bangunan.

1. Tujuan : mendapatkan view yang terbaik pada bangunan.

2. Dasar pertimbangan: letak entrance, kondisi view, arah pergerakan lalu lintas, sudut pandang dari jalan ke tapak.

3. Hasil analisis: view terbaik menghadap ke arah Jalan Kapten Haryadi, sehingga bangunan mengarah ke sisi tersebut, dengan dilakukan pengolahan bentuk sebagai point of interest.

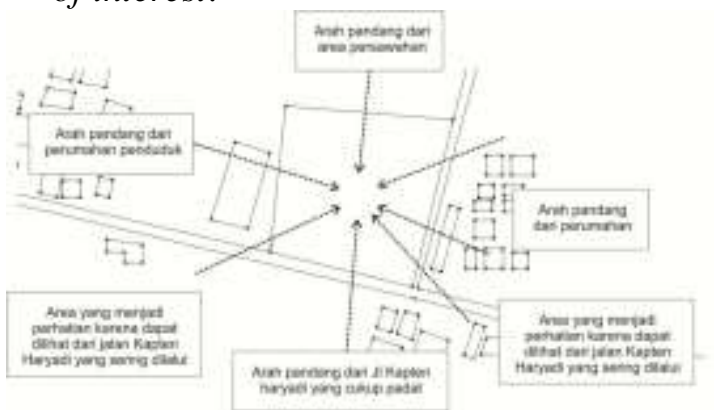

Gambar 5. Analisis View

\subsection{Analisis Kebisingan Tapak}

Analisis kebisingan tapak untuk menjaga kestabilan tingkat kebisingan di dalam bangunan.

1. Tujuan: mendapatkan kestabilan tingkat kebisingan di dalam bangunan agar tetap nyaman bagi fungsi bangunan Pusat Tari Modern.

2. Dasar pertimbangan: sumber kebisingan dari lingkungan sekitar tapak dan peletakkan massa bangunan.

3. Hasil analisis: kebisingan berasal dari arah selatan tapak yaitu Jalan Kapten Haryadi. (Gambar 6). Untuk mengurangi tingkat kebisingan di luar tapak diatasi dengan pemberian barrier vegetasi dan peletakkan bangunan menjauh dari pusat kebisingan terbesar (Gambar 7).

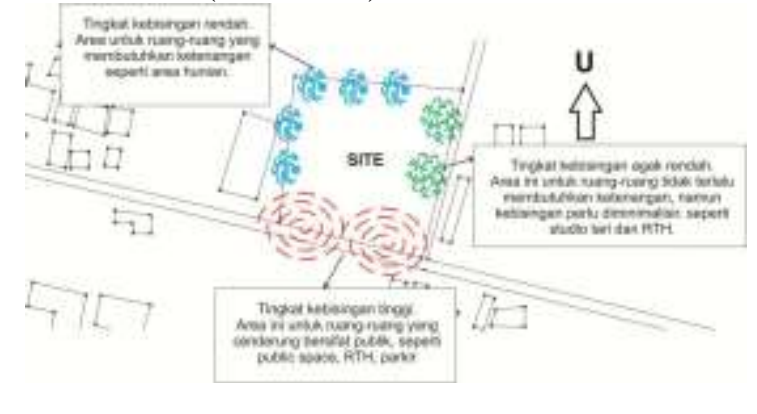


Gambar 6. Analisis Kebisingan Tapak

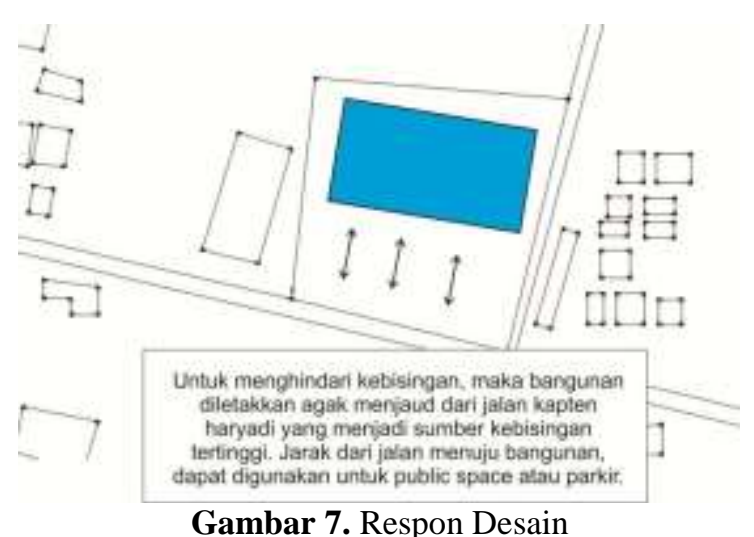

\subsection{Analisis Pemintakan}

Pemintakan digunakan untuk mendapatkan tata letak massa.

1. Tujuan: mendapatkan tata letak massa pada bangunan Pusat Tari Modern.

2. Dasar pertimbangan: analisis pencapaian, analisis matahari, analisis view, analisis kebisingan.

3. Hasil analisis:

Analisis pemintakan dikelompokkan berdasarkan zona publik, semi publik, semi privat, dan privat.

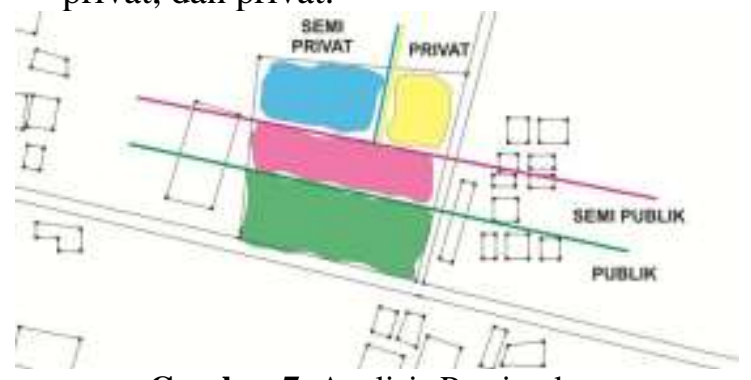

Gambar 7. Analisis Pemintakan

Ada 4 pemintakan pada tapak Pusat Tari Modern (Gambar 7). Pemintakan tersebut bertujuan untuk mendapatkan tata letak bangunan. Tata letaknya adalah sebagai berikut:

1. Bagian publik, digunakan untuk area parkir, bagian massa bangunan pertunjukkan dan bagian massa bangunan studio yang digunakan oleh pengunjung.

2. Bagian semi publik, digunakan untuk area amphitheatre, bagian massa bangunan pertunjukkan dan bagian massa bangunan studio yang digunakan oleh penari.

3. Bagian semi privat, digunakan untuk area latihan outdoor.
4. Bagian privat, digunakan untuk massa bangunan hunian.

\subsection{Analisis Bentuk Bangunan}

Dasar pertimbangan dari bentuk massa bangunan yaitu dari karakteristik tari modern.

1. Tujuan: mendapatkan konsep bangunan yang sesuai dengan bangunan Pusat Tari Modern dengan pendekatan arsitektur metafora yaitu karakteristik tari modern.

2. Dasar Pertimbangan: pengaplikasian karakteristik tari modern terhadap bangunan.

3. Hasil Analisis:

Bangunan Pusat Tari Modern mengaplikasikasikan karakteristik tari modern. Karakteristik yang dapat dijadikan sebagai penyelesaian permasalahan yaitu wujud, bentuk, dan alur gerak tari. Alur gerak tari dapat dilihat dari ekspresi gerak dari awal tarian, pertengahan, sampai pada akhir pertunjukkan. Dari alur gerak tari tersebut, muncul karakter tarian yang khas yatiu dinamis, estetis, dan kekontrasan.

a. Dinamis

1) Tampilan bangunan.

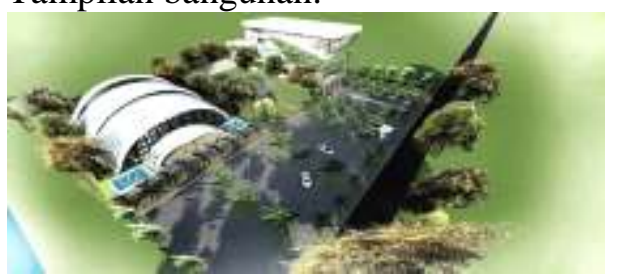

Gambar 8. Bentuk Bangunan

Tampilan massa menggunakan konsep dari gerakan tangan dan kaki saat menari. Pada saat menari, akan terjadi perubahan bentuk. Melalui perubahan bentuk tersebut, dihasilkan bentuk dinamis dari bentuk dasar yang mengalami pengurangan dan penambahan bentuk.

2) Tatanan massa.

Tatanan massa pada bangunan Pusat Tari Modern yaitu memiliki organisasi terpusat. Organisasi terpusat didapatkan dari formasi penari.

Alternatif gubahan massa yang akan digunakan adalah meletakkan beberapa massa terpisah menurut jenis ruangnya. Beberapa jenis ruang akan digabungkan supaya lebih efisien. 


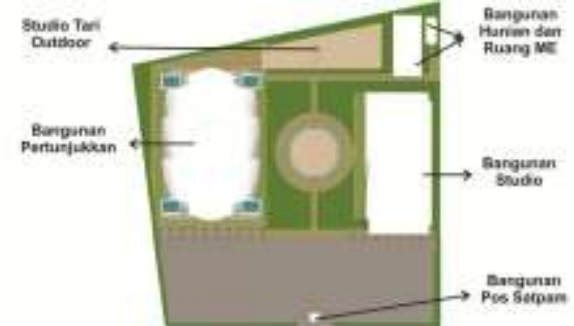

Gambar 9. Tatanan Massa

b. Estetis

1) Interior bangunan.

Nilai estetis dilihat dari unsur keselarasan merupakan perpaduan dari satu elemen dengan elemen yang lain membentuk satu kesatuan yang selaras.

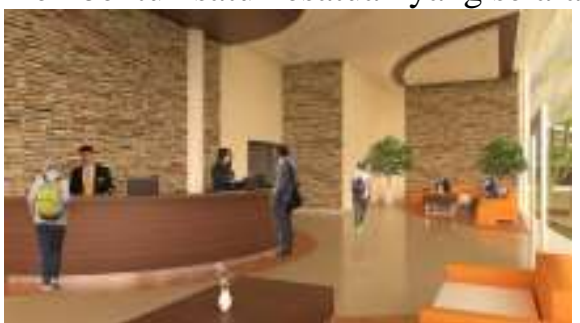

Gambar 10. Elemen Interior

2) Elemen dinding.

Nilai estetis dilihat dari unsur irama, dapat diwujudkan melalui elemen dinding dengan permainan perubahan skala dari lambat ke cepat kemudian melambat lagi.

Tari modern yang penuh irama, dapat digambarkan melalui kombinasi elemen garis lengkung dan lurus.

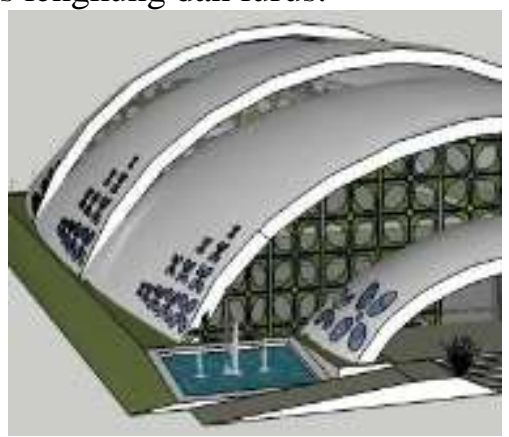

Gambar 11. Elemen Dinding

3) Gubahan massa.

Nilai estetis dapat dilihat dari unsur komposisi bangunan atau tatanan massa.

c. Kekontrasan

1) Keseluruhan massa.

Kekontrasan pada tari modern dapat dilihat dari perubahan gerak tari modern. Contoh penerapannya yaitu:
- Ruang-ruang yang didominasi bentuk statis terutama pada bentuk massa secara 3 dimensi.

- Ruang-ruang yang menggunakan bentuk dinamis pada massa bangunan secara 3 dimensi.

- Ruang-ruang privat dengan dominasi bentuk statis.

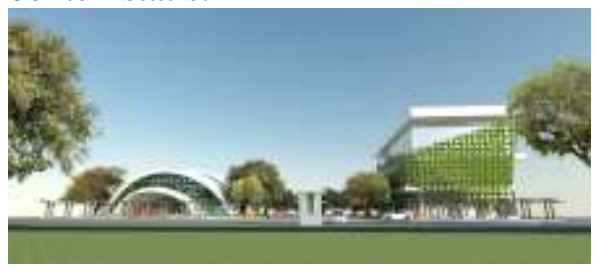

Gambar 12. Kekontrasan Bentuk

\subsection{Analisis Sistem Struktur}

1. Tujuan: memperoleh jenis struktur bangunan yang tepat dalam desain Pusat Tari Modern di Yogyakarta.

2. Dasar Pertimbangan: daya dukung terhadap kebutuhan dan konsep bangunan, serta kondisi eksisting tapak.

3. Hasil Analisis:

a. Upper Structure

Penggunaan struktur cangkang pada atap bangunan yang mempunyai bentang lebar seperti pada bangunan pertunjukkan. Pada beberapa bangunan direncanakan untuk menggunakan atap dak beton guna mendukung pengolahan bentuk bangunan.

b. Supper Structure

Supper structure yang direncanakan adalah dengan menggunakan struktur rangka, karena bangunan memiliki bentuk yang dinamis sehingga nantinya akan mudah mengatur letak tata kolom.

c. Sub Structure

Sub structure yang direncanakan adalah dengan menggunakan pondasi footplate, karena mengingat bangunan memiliki tinggi $2-3$ lantai.

\subsection{Analisis Material Bangunan}

Analisis material difokuskan pada ruang yang membutuhkan perhatian khusus seperti ruang studio tari dan ruang pertunjukkan.

1. Tujuan: penggunaan material khusus yang sesuai dengan kebutuhan ruang. 
2. Dasar pertimbangan: tata letak, pola lantai, fungsi ruang, kegiatan, struktur, akustik, dan mendukung suasana ruang.

3. Hasil analisis:

a. Langit-langit

1) Kriteria bahan: akustik, mendukung konstruksi, ringan, mudah perawatan, estetis.

2) Bahan: plafon akustik.

b. Dinding

1) Kriteria bahan: akustik, tahan gesek, tahan terhadap perubahan suhu, fleksibilitas ruang.

2) Bahan: ruang studio tari menggunakan dinding akustik dan cermin. Sedangkan ruang pertunjukkan menggunakan dinding akustik dan dinding lipat bertekstur.

c. Lantai

1) Kriteria bahan: akustik, tidak licin, mudah perawatan, daya pantul sinar tidak lebih dari $30 \%$.

2) Bahan: lantai parquet.

\subsection{Analisis Sistem Utilitas}

1. Tujuan: menerapkan sistem utilitas yang sesuai dengan kebutuhan bangunan.

2. Dasar Pertimbangan: beberapa ruang memiliki kebutuhan sistem utilitas yang berbeda sesuai fungsinya.

3. Hasil Analisis:

a. Sistem Pencahayaan

Penerapan sistem pencahayaan pada desain bangunan yaitu pencahayaan alami dan buatan. Pencahayaan alami dioptimalkan melalui bukaan berupa jendela, skylight, dan bouven. Sedangkan pencahayaan buatan, khususnya untuk ruang pertunjukkan menggunakan lampu parabolic aluminized reflector lights, spotlights, followspot, dan interlligent lights. Selain itu juga menggunakan lampu pijar untuk ruang rias.

b. Sistem Akustik

1) Analisa luar ruangan

Akustika luar ruangan diwujudkan dengan pengambilan jarak bangunan antara sumber kebisingan, adanya barrier berupa vegetasi, menggunakan pavingblock sebagai pelapis jalan, dan tata letak bangunan.
2) Analisa dalam ruangan

Akustika dalam ruangan

diwujudkan dengan pemilihan material terhadap langit-langit, dinding, dan lantai.

c. Sistem Penghawaan

Sistem penghawaan pada bangunan menggunakan AC unit, karena mudah dalam pengaturan suhu ruang yang berbeda-beda sesuai dengan fungsinya.

d. Sistem Air Bersih

Sumber air bersih yang digunakan pada tapak ini yaitu bersumber pada PDAM dan sumur artetis.

e. Sistem Air Kotor

Sistem air kotor pada tapak menggunakan septictank pada masingmasing bangunan.

f. Sistem Jaringan Listrik

Sumber energi listrik pada tapak yaitu berasal dari PLN dan genset.

\section{KESIMPULAN (KONSEP DESAIN)}

Berdasarkan hasil analisis perencanaan dan perancangan yang dilakukan, maka diperoleh konsep desain Pusat Tari Modern di Yogyakarta dengan Pendekatan Arsitektur Metafora sebagai berikut:

Lokasi : Jl. Kapten Haryadi, Ngaglik, Sleman, Yogyakarta.

Luas Lahan : kurang lebih $10.000 \mathrm{~m}^{2}$.

Luas bangunan : 9.891,13 $\mathrm{m}^{2}$.

Jumlah Lantai : 1 - 3 Lantai.

Penerapan Arsitektur Metafora pada bangunan Pusat Tari Modern di Yogyakarta berdasarkan karakteristik tari modern, yaitu dinamis, estetis, dan kekontrasan. Karakteristik tersebut diaplikasikan terhadap perancangan bangunan.

Gambar 13 memperlihatkan keseluruhan tapak Pusat Tari Modern. Penataan massa yang sesuai dengan pola formasi penari yaitu organisasi terpusat. Amphiteather sebagai pusat tata massa.

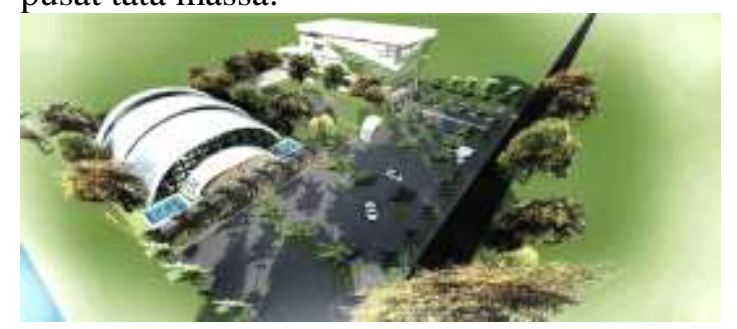

Gambar 13. Perspektif Tapak Pusat Tari Modern. 
Gambar 14 memperlihatkan area studio tari outdoor berupa ruang terbuka yang berfungsi sebagai tempat latihan tari modern.

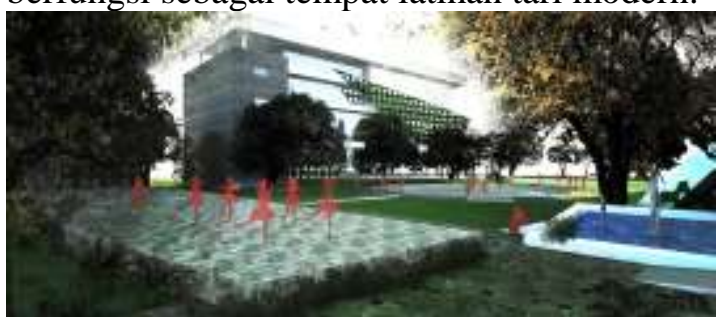

Gambar 14. Perspektif Studio Tari Outdoor

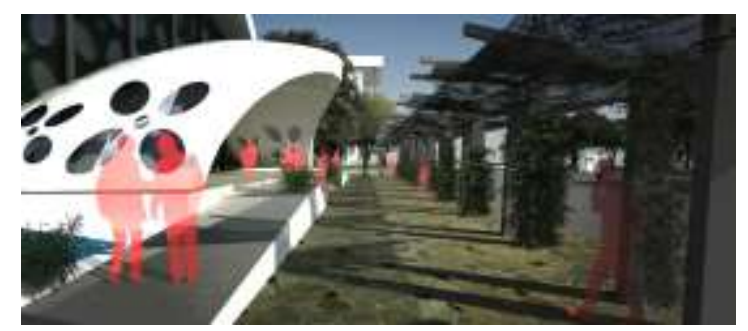

Gambar 15. Perspektif Sirkulasi Pintu Masuk Gedung Pertunjukkan

Gambar 15 memperlihatkan sirkulasi pada pintu masuk gedung pertunjukkan menerapkan bentuk lengkung yang mencirikan karakter dinamis pada bangunan. Terdapat pergola di depan pintu masuk untuk berteduh. Pergola didesain dengan ketinggian yang berbeda, menunjukkan karakter irama pada tari modern.

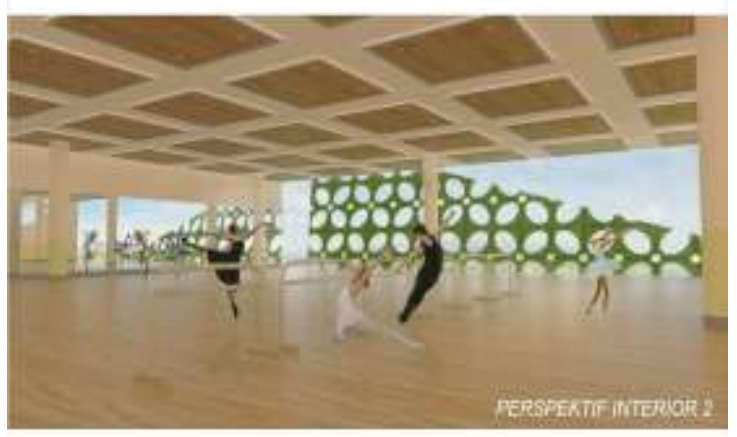

Gambar 16. Perspektif Interior Ruang Studio Tari Indoor.

Gambar 16 memperihatkan ruang studio tari indoor yang berfungsi sebagai tempat latihan tari modern. Ruangan ini memiliki ketinggian 8 meter, bertujuan untuk memberikan ruang gerak penari agar dapat secara maksimal mengembangkan diri.

\section{REFERENSI}

Jogja Dance Foundation. 2011. Data Jogja Dance Foundation. Yogyakarta.

Karatani, Kojin. 1995. Architecture as Metaphors. Columbia: MIT Press.

Pramono, Adi Tri. 2015. Padepokan Seni Bagong Kussudiardja.

http://www.jogjatrip.com/id /631/padepokan-seni-bagongkussudiardja. Diakses pada 114 Maret 2015. 